\title{
Characteristics of prolonged luteal phase identified by milk progesterone concentrations and its effects on reproductive performance in Holstein cows
}

\author{
R. M. S. B. K. Ranasinghe, ${ }^{\star}$ T. Nakao, ${ }^{\star 1}$ K. Yamada, $†$ K. Koike, ${ }^{\star 2}$ A. Hayashi, ${ }^{\star}$ and C. M. B. Dematawewał \\ *Laboratory of Theriogenology, Department of Veterinary Medicine, Faculty of Agriculture, Yamaguchi University, 1677-1 Yoshida, \\ Yamaguchi 753-8515, Japan \\ †Nemuro NOSAI, Shibetsu Large Animal Clinic, Shibetsu, Hokkaido, 086-1451, Japan \\ ‡Department of Animal Science, Faculty of Agriculture, University of Peradeniya, Peradeniya, Sri Lanka
}

\begin{abstract}
A database of milk progesterone profiles consisting 497 lactations in 3 dairy herds from northern and western regions of Japan was used to identify the characteristics and associated risk factors for prolonged luteal phase (PLP) and its effects on subsequent reproductive performance in high-producing Holstein cows. Milk samples were collected twice weekly and progesterone concentrations in whole milk were determined by ELISA. Herds were visited monthly and examined by vaginoscopy and transrectal palpation. Resumption of ovarian cyclicity within $35 \mathrm{~d}$ postpartum followed by regular cycles was considered normal. Prolonged luteal phase was defined when progesterone concentrations were $\geq 5 \mathrm{ng} / \mathrm{mL}$ for $\geq 20 \mathrm{~d}$ of duration in any cycle postpartum. Delay of first ovulation to 35 to $60 \mathrm{~d}$ (delayed first ovulation type I), $>60 \mathrm{~d}$ (delayed first ovulation type II), a luteal phase of $<14 \mathrm{~d}$ except in the first cycle (short luteal phase), and the absence of luteal activity $>14 \mathrm{~d}$ between 2 cycles (cessation of cyclicity) were the other categories of abnormal ovarian resumptions considered. The overall incidence of PLP in the 3 herds was $11.9 \%$ and a significantly higher proportion of PLP was observed in the first cycle postpartum compared with the second and third cycles. Approximately $83 \%$ of the PLP were 20 to $28 \mathrm{~d}$ in duration, and maximum progesterone concentration was significantly higher when PLP lasted $>35 \mathrm{~d}$ compared with PLP of 20 to $35 \mathrm{~d}$ in duration. Higher parity, commencement of luteal activity $\leq 28 \mathrm{~d}$ postpartum, and postpartum complications significantly increased the occurrence of PLP within $90 \mathrm{~d}$ postpartum. Cows with PLP showed reduced conception rate to first artificial insemination (AI) and reduced pregnancy proportions within 100, 150, and $210 \mathrm{~d}$ postpartum. Based on survival analysis,
\end{abstract}

Received February 28, 2010.

Accepted September 12, 2010.

${ }^{1}$ Corresponding author: tnakao@yamaguchi-u.ac.jp

${ }^{2}$ Present address: Hiroshima NOSAI, Yamagata Large Animal Clinic, Kita-Hiroshima, Hiroshima, 731-1531, Japan.
PLP was associated with a $56 \%$ reduction in relative pregnancy rate and a $36 \%$ reduction in AI submission rate. Cows that experienced PLP had a longer interval from calving to first AI $(74 \mathrm{~d})$ and from calving to pregnancy $(141 \mathrm{~d}$ ) than cows without PLP (53 and 80 d), respectively. In conclusion, $11.9 \%$ of lactations had PLP, of which approximately two-thirds were seen in the first cycle postpartum. Most of the PLP were 20 to $28 \mathrm{~d}$ in duration. Higher parity, postpartum complications, and early commencement of luteal activity postpartum increased the risk for PLP. Occurrence of PLP adversely affected fertility by reducing pregnancy proportions and extending calving to conception interval.

Key words: dairy cow, prolonged luteal phase, reproductive performance

\section{INTRODUCTION}

Infertility in high-yielding dairy cows worldwide represents a problem of increasing importance and causes considerable losses in the dairy industry. The resumption of normal ovarian cyclicity is one of the most important events to regain the maximum reproductive potential of the dairy cow following parturition (Opsomer et al., 2000). To attain a recommended calving interval of 12 to $13 \mathrm{mo}$, cows should conceive within $100 \mathrm{~d}$ after parturition, which requires early onset of ovarian activity followed by normal ovarian cycles, optimal estrous detection rates, and conception rates. Examination of milk progesterone profiles offers a convenient and objective method for the identification of postpartum ovarian activity in dairy cows. In recent years, an increased incidence of abnormal ovarian cycles during pre-service period in high-producing dairy cows has been reported from various countries (Opsomer et al., 2000; Royal et al., 2000; Shrestha et al., 2004a) and this could have contributed to the decline in reproductive performance of modern dairy cows.

Prolonged luteal phase (PLP; high progesterone concentration for $\geq 20 \mathrm{~d}$ of duration) has been reported as 1 of the 2 common types of abnormalities during the 
period from calving to $90 \mathrm{~d}$ postpartum in dairy cows (Lamming and Darwash, 1998; Opsomer et al., 2000; Royal et al., 2000; Shrestha et al., 2004a). A longer luteal phase would complicate reproductive management in dairy cows because it may delay rebreeding, making it more difficult to predict the day when cyclic cows will return to estrus.

Based on milk progesterone profiles, an increased number of cows have been diagnosed as having PLP in many dairy herds (Opsomer et al., 1998, 2000; Shrestha et al., 2004a; Hommeida et al., 2005). However, the results show great differences among different herds, which suggests that an important part is played by management factors. Therefore, further epidemiological studies are necessary to look for risk factors in different regions or countries to describe the causes of PLP.

The effects of PLP on subsequent reproductive performance of dairy cows remain controversial. Some studies reported that cows with PLP had significantly lower first-AI conception rates, more services per conception, and more days open compared with cows with normal resumption of ovarian activity (Lamming and Darwash, 1998; Royal et al., 2000; Shrestha et al., 2004b; Hommeida et al., 2005), whereas some other studies reported that occurrence of PLP did not affect the above-mentioned fertility parameters (Taylor et al., 2003; Samarütel et al., 2008; Gautam et al., 2010).

Therefore, the objectives of the present study were to describe (1) the characteristics of PLP, (2) the associated risk factors, and (3) the effects of PLP on subsequent reproductive performance of high-producing Holstein cows.

\section{MATERIALS AND METHODS}

\section{Animals and Management}

This study was conducted in 301 Holstein-Friesian cows calving from September 2005 to April 2009 from 3 commercial dairy herds in Japan and included 497 lactations. Herd A was located in Hokkaido in northeastern Japan. Herds B and C were located in Yamaguchi Prefecture in southwestern Japan. The criteria for inclusion of the herds were routine monitoring of postpartum dairy cows through milk progesterone measurements conducted at the Laboratory of Theriogenology, Yamaguchi University (Yamaguchi, Japan) for reproductive management of dairy cows, and participation in the DHIA programs. Cows in herds A and B were confined throughout the year in a freestall barn with sawdust (herd A with 150 cows) or wood shavings (herd B with 60 cows) for bedding. In herd C, cows were kept in a tie-stall barn with an open paddock, which was used when cows were sent outdoors twice a day. The cows were nonseasonal, year-round calvers, and they were milked twice daily with a herd-average milk yield of 10,100, 8,700, and 9,246 kg over a 305-d period for herds A, B, and C, respectively. The parity of the cows ranged from 1 to 8 with the mean $( \pm \mathrm{SD})$ of $3 \pm 2$. On all farms, animals were fed a TMR containing grass silage, wheat pulp, concentrates, and calcium and magnesium phosphates throughout all seasons to meet the nutritional requirements of lactation.

\section{Estrus Detection, Al, and Pregnancy Diagnosis}

In herd A, estrus detection was performed using pedometers (AFI 2000, AfiFarm System, SAE Afikim, Israel) in combination with visual observation. Cows that were in estrus during the night were detected using pedometers. Those with increased walking activity were inspected for the primary estrous signs (standing to be mounted) and any secondary estrous signs, such as swelling, relaxation, and congestion of the vulva, or mucus discharge from the vulva. After previous breeding records were checked, AI was performed generally 6 to $15 \mathrm{~h}$ after walking activity increased. Cows were visually observed for behavioral signs of estrus around noon, at $1600 \mathrm{~h}$ (before the afternoon milking), and whenever the farmer could observe them. In herds B and $\mathrm{C}$, estrus detection was based on visual observation and cows were inspected for signs of estrus in the morning, at noon, and late in the afternoon; standing to be mounted was considered the primary sign of being in estrus. In addition, the following estrus detection aids were used on farm B: Kamar heat mount detector (Kamar Inc., Steamboat Springs, CO) and Estrotect heat detector (Estrotect Inc., Rockway, CO). For all herds, if standing estrus was observed in the morning, those cows were inseminated in the afternoon, whereas, if standing estrus was observed in the afternoon, they were inseminated the following morning.

In herd A, inseminations were performed by an experienced technician from the dairy co-operative and in farms B and C by the herd owners, using frozen-thawed semen of proven sires from the Livestock Improvement Association of Japan (Tokyo). The voluntary waiting period before the first AI was 35 to $40 \mathrm{~d}$ in all herds. Pregnancy was diagnosed by transrectal palpation by the third author on farm A, whereas it was done by transrectal palpation and ultrasonography (Tringa Linear Vet, equipped with dual-frequency $5 / 7.5 \mathrm{MHz}$ transrectal transducer; Pie Medical Equipment BV, Maastricht, the Netherlands) on farms B and C by the first and second authors. 
Table 1. Classification of resumption of ovarian activity postpartum in Holstein cows based on milk progesterone profiles ( $\mathrm{n}=497$ lactations)

\begin{tabular}{|c|c|c|c|}
\hline Category & Description & $\mathrm{n}$ & $\%$ \\
\hline Prolonged luteal phase & $\begin{array}{l}\text { A luteal phase of } \geq 20 \mathrm{~d} \text { of duration after first, second, or third } \\
\text { ovulation without a preceding insemination }\end{array}$ & 59 & 11.9 \\
\hline \multicolumn{4}{|l|}{ Other abnormal ovarian resumptions } \\
\hline Delayed ovulation type I & First ovulation between 36 and $60 \mathrm{~d}$ postpartum & 118 & 23.7 \\
\hline Delayed ovulation type II & First ovulation $>60 \mathrm{~d}$ postpartum & 48 & 9.7 \\
\hline Subtotal ("other" group) & & 207 & 41.6 \\
\hline
\end{tabular}

\section{Reproductive Examination}

Each herd (herd A by the third author; herds B and $\mathrm{C}$ by a team including all the authors except the third and sixth authors and headed by the senior author) was visited once a month for regular reproductive examinations, which included clinical examination of all postpartum cows enrolled in the monitoring program by milk progesterone measurements, the detection and treatment of reproductive disorders, and pregnancy diagnosis. Cows that were $>14 \mathrm{~d}$ postpartum were included in the study and were examined every month until pregnancy or culling (herds B and C) or 90 d postpartum (herd A).Vaginoscopy and transrectal palpation were the routine examinations. If the cow was $\leq 1$ mo after AI and did not return to estrus, only vaginoscopy was performed. If the cow was $>1$ mo after AI, pregnancy diagnosis was done using ultrasonography. All other cows were examined vaginoscopically, followed by transrectal palpation of the reproductive tract. The presence and nature of discharge in the vagina or the external cervical os were examined and the condition was scored qualitatively as no discharge, clear mucus, predominantly clear mucus with some flecks of pus, mucopurulent (approximately $50 \%$ pus and $50 \%$ mucus), or purulent ( $>50 \%$ pus). Cows with either mucopurulent or purulent discharge on vaginoscopy were defined as endometritis. During palpation diameter of the cervix, diameter, consistency (contraction, elasticity, and tonicity), and symmetry of uterine horns (i.e., differences in diameter), the presence of any fluid in the uterus, and the presence of any palpable structures (e.g., Graafian follicle, corpus luteum, or cysts) in the ovaries and their diameters were examined.

\section{Milk Sampling and Progesterone Assay}

Milk samples were collected twice weekly, Monday and Thursday, from 14 to $90 \mathrm{~d}$ postpartum (herd A) or until diagnosed pregnant or a decision was made for culling (herds B and C). Approximately $10 \mathrm{~mL}$ of foremilk was collected from each quarter during the afternoon milking into a plastic tube $(10.5 \times 1.5 \mathrm{~mm})$ containing $15 \mathrm{mg}$ of potassium dichromate (Wako Pure Chemical Industries Ltd., Osaka, Japan) as the preservative. After collection, samples were mixed well, stored at $4^{\circ} \mathrm{C}$, and sent to the Laboratory of Theriogenology, Yamaguchi University for progesterone assay within 2 wk after collection. At this laboratory, the samples were again mixed well, stored at $4^{\circ} \mathrm{C}$, and analyzed for progesterone concentrations within 3 to $5 \mathrm{~d}$ of receipt.

Progesterone concentrations in whole milk were measured by direct ELISA (Isobe et al., 2004). The sensitivity of the direct ELISA for milk progesterone, calculated from the mean value at $0 \mathrm{ng} / \mathrm{mL}$ of progesterone minus 2 standard deviations, was estimated as $26 \mathrm{pg} / \mathrm{mL}(0.65 \mathrm{pg} /$ well $)$. The intraassay $\mathrm{CV}$ of milk progesterone concentrations measured by the ELISA was $4.8 \%(\mathrm{n}=6$, mean $=30.0 \mathrm{ng} / \mathrm{mL})$ and $11.5 \%(\mathrm{n}$ $=6$, mean $=4.0 \mathrm{ng} / \mathrm{mL}$ ) for high and low controls, respectively. The interassay CV was $14.3 \%(\mathrm{n}=6)$ and $19.1 \%(\mathrm{n}=6)$ for high and low controls, respectively. For the purpose of this study, progesterone profiles of cows up to $90 \mathrm{~d}$ postpartum were used. Cows with milk progesterone concentrations of $\geq 5 \mathrm{ng} / \mathrm{mL}$ in at least 2 consecutive samples were considered to have a functional corpus luteum (Isobe et al., 2004). Different categories of ovarian resumption postpartum based on milk progesterone profiles are given in Table 1.

\section{Data Collection and Calculation of Reproductive Parameters}

Data were collected from 301 cows (497 lactations). On farms B and C, on the day of each visit, new information of any cow entering the study was obtained from the herd owner. Such information included the date of calving, calving condition [normal or dystocia (i.e., any difficulty in calving that required assistance)], retention (no expulsion of fetal membranes within $24 \mathrm{~h}$ after calving) or normal expulsion of fetal membranes (expulsion within $24 \mathrm{~h}$ after calving), parity, postpar- 
tum uterine infections (endometritis, metritis, or pyometra), presence of metabolic diseases (ketosis or milk fever), presence of other diseases such as mastitis and lameness, date of insemination, and decision of culling. On farm A, the above information was collected during monthly visits by the third author.

Reproductive performance data were collected for a minimum of $210 \mathrm{~d}$ postpartum or until pregnancy or culling. First-AI conception rate was calculated as the proportion of cows that conceived after the first insemination postpartum. Pregnancy proportions within 100, 150 , and $210 \mathrm{~d}$ were calculated as the number of cows that became pregnant within those periods divided by the total number of breedable cows in the herd. A 100-d pregnancy proportion was considered an important reproductive end-point to have a calving interval of 12 to 13 mo. The 150-d pregnancy proportion was considered an economically important measure of reproductive performance because the average calving to conception interval in dairy cows in Japan is $158 \mathrm{~d}$ (Nakada, 2006). The 210-d pregnancy proportion was also used as a reproductive performance parameter because herd owners generally decide to cull a cow if it does not conceive within 7 mo postpartum.

\section{Data Management and Statistical Analysis}

Overall, 497 lactations in 301 cows were studied. The proportion of animals showing normal and abnormal categories of ovarian resumption postpartum was expressed as a percentage of the total number of cows examined. Incidence of PLP in each herd, proportion of cows with PLP at first, second, or third estrous cycles postpartum and different durations of PLP were given as percentages. Maximum progesterone concentration of PLP among groups of cows with different duration of PLP was given as mean $\pm \mathrm{SD}$ and examined using ANOVA. Proportions of cows in different categories were compared by chi-squared test. Fisher's exact test was used when one or more cells had an expected value $<5$.

Variables associated with PLP were initially checked in the univariate analysis. Multivariable logistic regression was used to build a best-fitting model for variables associated with PLP, using all variables that were associated with an outcome of interest $(P<0.25)$ in the univariate analysis. Herd (A, B, or C), parity (primiparous or multiparous), average milk yield per day during $90 \mathrm{~d}$ postpartum (low, moderate, or high, based on the average and standard deviation of the group concerned), average milk fat content per day during 90 d postpartum (low, moderate, or high, based on the average and standard deviation of the group concerned), average milk protein content per day during $90 \mathrm{~d}$ postpartum $(<3.0 \%$ or $\geq 3.0 \%)$, season of calving (winter, December to February; spring, March to May; summer, June to August; or autumn, September to November), postpartum complications (dystocia, retention of fetal membranes, endometritis, metritis, or pyometra), interval from calving to commencement of luteal activity ( $\leq 21 \mathrm{~d}, 22$ to $28 \mathrm{~d}, 29$ to $35 \mathrm{~d}$, or $>35 \mathrm{~d}$ ), and cow effect were included in the initial models of logistic regression procedure. However, because cow effect was found to be nonsignificant $(P>0.89)$, it was excluded from the final model.

To study the effect of PLP on each fertility endpoint, conception to first AI, and pregnancy proportions within 100, 150, and $210 \mathrm{~d}$, a separate model was built for each in a multivariable logistic regression procedure. In addition to herd, parity, milk yield, milk fat, milk protein, season of calving, mastitis (present or absent) and metabolic diseases (hypocalcaemia and ketosis; present or absent) were offered to all models as covariates. Presence of at least one of the following conditions - dystocia, retention of fetal membranes, endometritis, metritis, or pyometra-was categorized as postpartum complications. Variables that were not significant $(P>0.1)$ were removed by a backward stepwise procedure using likelihood-ratio test. If one level of a categorical variable was significant, all levels were retained. Potential 2-way interactions were tested for significance $(P<0.05)$ only between the variables in which the main effects were significant. Final models were assessed using the Hosmer-Lemeshow goodness of fit test.

The effect of PLP on time to pregnancy and time to first insemination were analyzed by multivariable survival analysis using Cox's proportional hazards regression. In addition to the main effect, the effects of all the variables included in the logistic regression procedure for fertility end-points were offered to the models as covariates. Models were built by manual backward stepwise elimination, removing the covariate with the largest probability value at each step, until all covariates were significant at $P<0.05$. If one level of a categorical variable was significant, all levels were retained. Potential 2-way interactions were evaluated for significant variables. Kaplan-Meier survival function estimates were used to calculate crude associations of PLP, normal, and other abnormal resumption of ovarian activity postpartum with median time from calving to conception and from calving to first insemination, as well as to generate graphs of cumulative proportion pregnant and inseminated over time. All analyses were performed with SPSS version 15.0 (SPSS Inc., Chicago, IL), with lactation as the experimental unit. 
Table 2. Incidence of prolonged luteal phase (PLP) in postpartum estrous cycles, duration and maximum milk progesterone concentration of PLP in Holstein cows $(\mathrm{n}=497$ lactations)

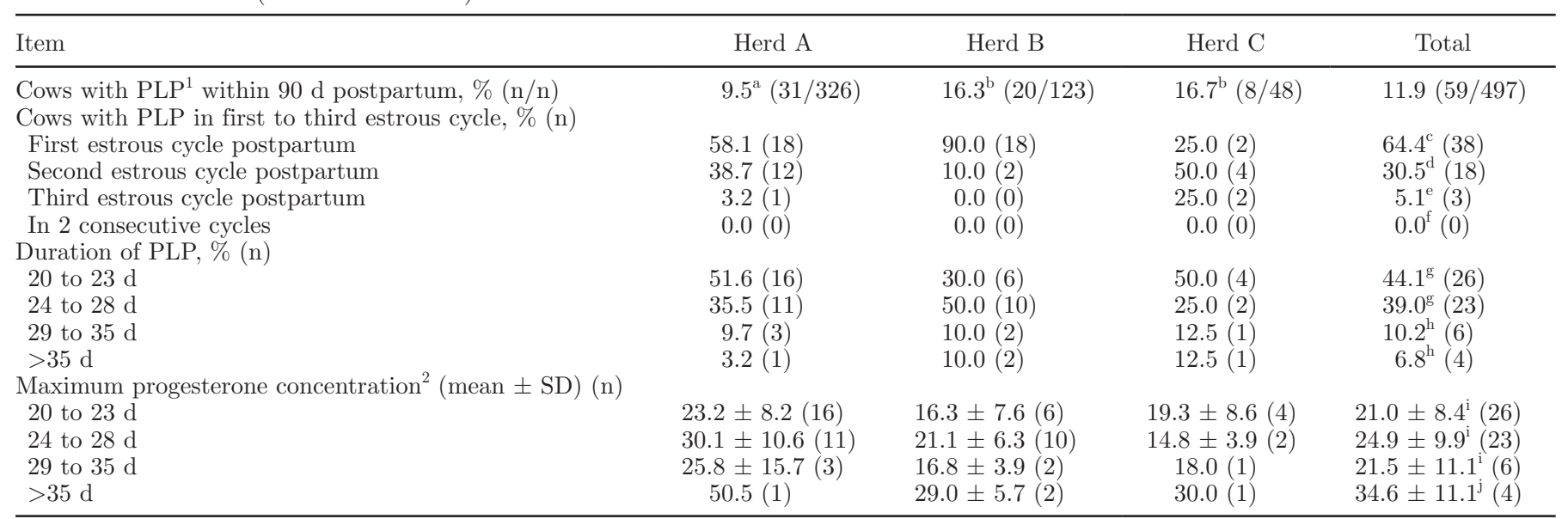

\footnotetext{
${ }^{\mathrm{a}, \mathrm{b}}$ Values within a row with different superscripts differ significantly $(P<0.1)$.

${ }^{\mathrm{e}, \mathrm{f}}$ Values within a column with different superscripts differ significantly $(P<0.1)$.

${ }^{\mathrm{i}, \mathrm{j}}$ Values within a column with different superscripts differ significantly $(P<0.05)$.

$\mathrm{c}, \mathrm{d} ; \mathrm{c}, \mathrm{e} ; \mathrm{c}, \mathrm{f} ; \mathrm{d}, \mathrm{e} ; \mathrm{d}, \mathrm{f} ;$ and g,h Values within a column with different superscripts differ significantly $(P<0.001)$.

${ }^{1}$ Prolonged luteal phase; a luteal phase of $\geq 20 \mathrm{~d}$ of duration after first, second, or third ovulation without a preceding insemination.

${ }^{2}$ Highest milk progesterone concentration $(\mathrm{ng} / \mathrm{mL})$ measured during PLP.
}

\section{RESULTS}

During the study period, 497 lactations in 301 cows were monitored by milk progesterone concentrations for the resumption of ovarian activity postpartum. Those data were used to identify the characteristics of PLP and to show the effects of PLP on subsequent reproductive performance in Holstein cows.

\section{Incidence and Characteristics of PLP}

Of the total 497 lactations, 231 (46.5\%), 59 (11.9\%), and $207(41.6 \%)$ cows were classified as having normal resumption of ovarian cyclicity, PLP, and other abnormal ovarian resumptions postpartum, respectively ( $\mathrm{Ta}-$ ble 1). The incidence of PLP among the herds ranged from 9.5 to $16.7 \%$ (Table 2). Of the 59 cows identified as having PLP based on milk progesterone profiles, $64.4 \%$ had PLP at the first cycle, $30.5 \%$ at the second cycle, and $5.1 \%$ at the third cycle. In the present study, none of the cows had PLP in 2 consecutive cycles. Approximately $83 \%$ of the PLP lasted 20 to $28 \mathrm{~d}$ ( $44.1 \%$ lasted 20 to $23 \mathrm{~d}$ and $39 \%$ lasted 24 to $28 \mathrm{~d}$ ). Only $6.8 \%$ of cows showed PLP of $>35 \mathrm{~d}$ in duration (Table 2 ). Cows with PLP $>35$ d showed significantly higher maximum progesterone concentrations compared with those with PLP lasting 20 to $35 \mathrm{~d}(P=0.05$; Table 2). Among cows with other types of abnormal ovarian resumptions postpartum, the greatest proportion of cows showed delayed ovulation type I (23.7\%; Table 1$)$.

\section{Risk Factors for PLP}

The risk factors assessed for their effects on PLP in Holstein cows during $90 \mathrm{~d}$ postpartum are shown in Table 3. Logistic regression analysis for the risk factors for PLP indicated no significant effects of herd or cow or average milk yield during $90 \mathrm{~d}$ postpartum or average milk fat content during $90 \mathrm{~d}$ postpartum or season of calving on the occurrence of PLP. The factors that significantly increased the risk of PLP within the studied cows were parity $(P=0.011)$, interval to commencement of luteal activity postpartum $(P<$ $0.001)$, postpartum complications $(P<0.001)$, and average milk protein content during $90 \mathrm{~d}$ postpartum $(P=0.056$; Table 4$)$. In multiparous cows, the odds of having PLP were 3.3 times greater than the odds of primiparous cows. Commencing luteal activity within 29 to $35 \mathrm{~d}$ and $>35 \mathrm{~d}$ postpartum had a lower risk for having PLP compared with cows with luteal activity commencing $\leq 21 \mathrm{~d}$ postpartum [odds ratio $(\mathbf{O R})=$ 0.41 and 0.14 , respectively]. For the cows with postpartum complications, the odds of having PLP were 5.1 times greater than those for healthy cows being diagnosed with PLP. Among the 2-way interactions tested between pairs of significant variables, only the interaction between postpartum complications and parity was significant. Multiparous cows with postpartum complications had a greater risk for the prevalence of PLP compared with primiparous healthy cows (OR $=4.46, P=0.009)$. 
Table 3. Risk factors assessed for their effects on prolonged luteal phase (PLP) in Holstein cows during $90 \mathrm{~d}$ postpartum ( $\mathrm{n}=497$ lactations)

\begin{tabular}{|c|c|c|c|}
\hline \multirow[b]{2}{*}{ Risk factor } & \multirow[b]{2}{*}{ Class } & \multicolumn{2}{|c|}{ PLP } \\
\hline & & $\mathrm{n}$ & $\%$ \\
\hline \multirow[t]{3}{*}{ Herd } & A & 31 & 9.5 \\
\hline & B & 20 & 16.3 \\
\hline & $\mathrm{C}$ & 8 & 16.7 \\
\hline \multirow[t]{2}{*}{ Parity } & Primiparous & 6 & 4.7 \\
\hline & Multiparous & 53 & 14.4 \\
\hline \multirow[t]{4}{*}{ Season of calving ${ }^{1}$} & Winter & 20 & 15.4 \\
\hline & Spring & 10 & 8.5 \\
\hline & Summer & 7 & 6.1 \\
\hline & Autumn & 12 & 8.9 \\
\hline \multirow[t]{2}{*}{ Postpartum complications $^{2}$} & No & 27 & 7.5 \\
\hline & Yes & 32 & 23.0 \\
\hline \multirow[t]{3}{*}{ Average milk yield (kg/d) } & $<26.9$ & 4 & 6.1 \\
\hline & $26.9-41.9$ & 43 & 12.4 \\
\hline & $>41.9$ & 12 & 14.5 \\
\hline \multirow[t]{3}{*}{ Average milk fat (\%/d) } & $<3.1$ & 4 & 16.0 \\
\hline & $3.1-4.3$ & 49 & 11.7 \\
\hline & $>4.3$ & 6 & 11.1 \\
\hline \multirow[t]{2}{*}{ Average milk protein $(\% / \mathrm{d})$} & $<3.0$ & 33 & 13.6 \\
\hline & $\geq 3.0$ & 26 & 10.2 \\
\hline \multirow[t]{4}{*}{ Commencement of luteal activity postpartum } & $\leq 21 \mathrm{~d}$ & 14 & 20.0 \\
\hline & $\overline{22}-28 \mathrm{~d}$ & 19 & 22.6 \\
\hline & $29-35 \mathrm{~d}$ & 12 & 12.9 \\
\hline & $>35 \mathrm{~d}$ & 14 & 5.6 \\
\hline
\end{tabular}

${ }^{1}$ Winter $=$ December to February; spring $=$ March to May; summer = June to August; autumn = September to November.

${ }^{2}$ Postpartum complications: presence of dystocia, retained fetal membranes, endometritis, metritis, or pyometra.

\section{Effect of PLP on Subsequent Reproductive Performance}

The effects of PLP on various reproductive endpoints are shown in Table 5. Adjusted to various covariates, cows with PLP showed lower conception rate to first $\mathrm{AI}(\mathrm{OR}=0.50 ; P=0.035)$, lower pregnancy proportions within $100 \mathrm{~d}(\mathrm{OR}=0.28 ; P<0.001), 150$
$\mathrm{d}(\mathrm{OR}=0.35 ; P=0.001)$, and $210 \mathrm{~d}(\mathrm{OR}=0.41 ; P$ $=0.013)$ postpartum compared with cows with normal resumption of ovarian cyclicity postpartum. Likewise, cows with other abnormal ovarian resumptions showed similar decline in reproductive performance (Table 5). Other than the main effect of interest (resumption of ovarian cyclicity postpartum), the occurrence of postpartum complications was significantly associated with

Table 4. Adjusted odds ratios (OR) and 95\% CI of the variables included in the final logistic regression model for risk factors for prolonged luteal phase in Holstein cows $(\mathrm{n}=497$ lactations)

\begin{tabular}{|c|c|c|c|c|c|c|}
\hline Variable $^{1}$ & Level & $\mathrm{n}$ & $\begin{array}{l}\text { Relative } \\
\text { risk }\end{array}$ & OR & $95 \% \mathrm{CI}$ & $P$-value \\
\hline Parity & $\begin{array}{l}\text { Primiparous } \\
\text { Multiparous }\end{array}$ & $\begin{array}{r}6 \\
53\end{array}$ & $\overline{1.20}$ & $\overline{3.31}$ & 1.32 to 8.28 & 0.011 \\
\hline Commencement of luteal activity postpartum & $\begin{array}{l}\leq 21 \mathrm{~d} \\
22-28 \mathrm{~d} \\
29-35 \mathrm{~d} \\
>35 \mathrm{~d}\end{array}$ & $\begin{array}{l}14 \\
19 \\
12 \\
14\end{array}$ & $\begin{array}{r}\overline{0} \\
-0.26 \\
-0.90 \\
-1.95\end{array}$ & $\begin{array}{l}- \\
1.30 \\
0.41 \\
0.14\end{array}$ & $\begin{array}{l}0.55 \text { to } 3.04 \\
0.16 \text { to } 1.02 \\
0.06 \text { to } 0.34\end{array}$ & $\begin{array}{r}0.552 \\
0.055 \\
<0.001\end{array}$ \\
\hline Average milk protein $(\mathrm{kg} / \mathrm{d})$ & $\begin{array}{l}<3.0 \\
\geq 3.0\end{array}$ & $\begin{array}{l}33 \\
26\end{array}$ & $\overline{-0.59}$ & $\overline{0.55}$ & 0.30 to 1.02 & 0.056 \\
\hline
\end{tabular}

${ }^{1}$ Model included herd, milk yield, milk fat, and season of calving.

${ }^{2}$ Included dystocia, retention of fetal membranes, endometritis, metritis, or pyometra. 
Table 5. Adjusted odds ratios (OR) and 95\% CI for different reproductive performance end points in Holstein cows with prolonged luteal phase and in those with other abnormal ovarian cycles versus normal resumption of ovarian activity postpartum $(\mathrm{n}=497$ lactations)

\begin{tabular}{|c|c|c|c|c|c|}
\hline End point ${ }^{1}$ & Level & Relative risk & OR & $95 \% \mathrm{CI}$ & $P$-value \\
\hline \multicolumn{6}{|l|}{ Conception to first AI } \\
\hline Normal ovarian resumption & $45.9(106 / 231)$ & - & - & & \\
\hline \multicolumn{6}{|c|}{ Pregnancy proportion within $100 \mathrm{~d}$ postpartum } \\
\hline Normal ovarian resumption & $60.6(140 / 231)$ & - & - & & \\
\hline Prolonged luteal phase & $23.7(14 / 59)$ & -1.27 & 0.28 & 0.14 to 0.56 & $<0.001$ \\
\hline Normal ovarian resumption & $78.8(182 / 231)$ & - & - & & \\
\hline Prolonged luteal phase & $49.2(29 / 59)$ & -1.06 & 0.35 & 0.18 to 0.66 & 0.001 \\
\hline Other abnormal ovarian resumptions & $57.5(119 / 207)$ & -0.82 & 0.44 & 0.28 to 0.69 & $<0.001$ \\
\hline \multicolumn{6}{|c|}{ Pregnancy proportion within $210 \mathrm{~d}$ postpartum } \\
\hline Normal ovarian resumption & $87.0(201 / 231)$ & - & - & & \\
\hline Prolonged luteal phase & $67.8(40 / 59)$ & -0.90 & 0.41 & 0.20 to 0.83 & 0.013 \\
\hline Other abnormal ovarian resumptions & $70.5(146 / 207)$ & -0.86 & 0.40 & 0.26 to 0.71 & 0.001 \\
\hline
\end{tabular}

${ }^{1} \mathrm{~A}$ separate model was used for each parameter, and each model initially included herd, parity, season of calving, mastitis postpartum complications, metabolic diseases, milk yield, milk fat, milk protein, and type of ovarian resumption postpartum.

reduced pregnancy proportions within 100, 150, and 210 $\mathrm{d}$ postpartum $(\mathrm{OR}=0.61,0.66$ and 0.63 , respectively; Table 6). Cows with metabolic diseases were less likely to become pregnant within 150 or $210 \mathrm{~d}$ postpartum and less likely to conceive to first $\mathrm{AI}(\mathrm{OR}=0.43,0.50$ and 0.84 , respectively), compared with cows that did not have metabolic diseases (Table 6). Similarly, for cows with mastitis, the odds of being pregnant within 150 and $210 \mathrm{~d}$ were 0.45 and 0.40 lower than the odds for healthy cows being pregnant within 150 and $210 \mathrm{~d}$ postpartum, respectively. Parity significantly affected pregnancy proportion within $100 \mathrm{~d}(\mathrm{OR}=0.57)$, but did not affect the other fertility end-points. None of the 2 -way interactions tested between the pairs of significant variables was found to be significant for the above 4 models.

Adjusted for covariates, PLP was associated with a $53 \%$ [hazard ratio $(\mathbf{H R})=0.47$ ] reduction in relative pregnancy rate and a $36 \%(\mathrm{HR}=0.64)$ reduction in $\mathrm{AI}$ submission rate (Table 7 ). Occurrence of PLP in any cycle postpartum, therefore, had a risk of pregnancy/ unit time of $47 \%$ compared with that of a similar cow with normal resumption of ovarian activity. In the final models, metabolic diseases $(\mathrm{HR}=0.75 ; P=0.036)$ and high milk yield $(\mathrm{HR}=0.65 ; P=0.021)$ were also significantly associated with reduced pregnancy rate. Both relative pregnancy rate and time to first insemination were influenced by herd, mastitis, and milk protein content. In the above 2 models for fertility end-points, none of the possible interactions were significant $(P>$ 0.05). The interval from calving to conception in cows that had PLP was delayed by $61 \mathrm{~d}$ relative to those that had normal resumption of ovarian cyclicity postpartum (median d 141 and 80, $P<0.001$; Figure 1). Likewise, median days to first insemination were longer (74 and $53 \mathrm{~d}, P=0.001$; Figure 2) in cows with PLP compared with cows that had normal resumption of ovarian cyclicity postpartum. Similarly, the other abnormal ovarian resumptions postpartum showed delayed interval from calving to conception (median d 120 and 80, $P<0.001$; Figure 1) and calving to first insemination (d 64 and $53, P=0.001$; Figure 2).

\section{DISCUSSION}

Normal resumption of ovarian cyclicity is a prerequisite to gain the maximum reproductive efficiency of the postpartum dairy cow. Among the different types of abnormal ovarian cycles identified by milk progesterone concentrations, PLP appears to be the second most prevalent abnormality reported from many dairy herds around the world (Opsomer et al., 2000; Royal et al., 2000; Shrestha et al., 2004a; Samarütel et al., 2008). Although some risk factors for PLP have been identified (Opsomer et al., 2000; Shrestha et al., 2004b), its effect on fertility remains questionable. To our knowledge, this study is one of the few that has investigated the characteristics, risk factors, and the effect of PLP on subsequent reproductive performance of Holstein cows.

The overall incidence of PLP in the current study was $11.9 \%$ and ranged from 9.5 to $16.7 \%$ in the 3 herds, slightly less than in some of the previous reports of Holstein cows, in which PLP was reported to be $20.0 \%$ (Opsomer et al., 1998), 17.6\% (Royal et al., 2000), 27.0\% (Taylor et al., 2003), 31.5\% (Shrestha et al., 2004a), 28.3\% (Hommeida et al., 2005), and 33.6\% (Shrestha et al., 2005). In contrast, an estimate of $15.5 \%$ was reported in Estonian Holstein cows (Samarütel et al., 
Table 6. Adjusted odds ratios (OR) and 95\% CI of the other variables that were significantly associated with different reproductive performance end points in Holstein cows ( $\mathrm{n}=497$ lactations)

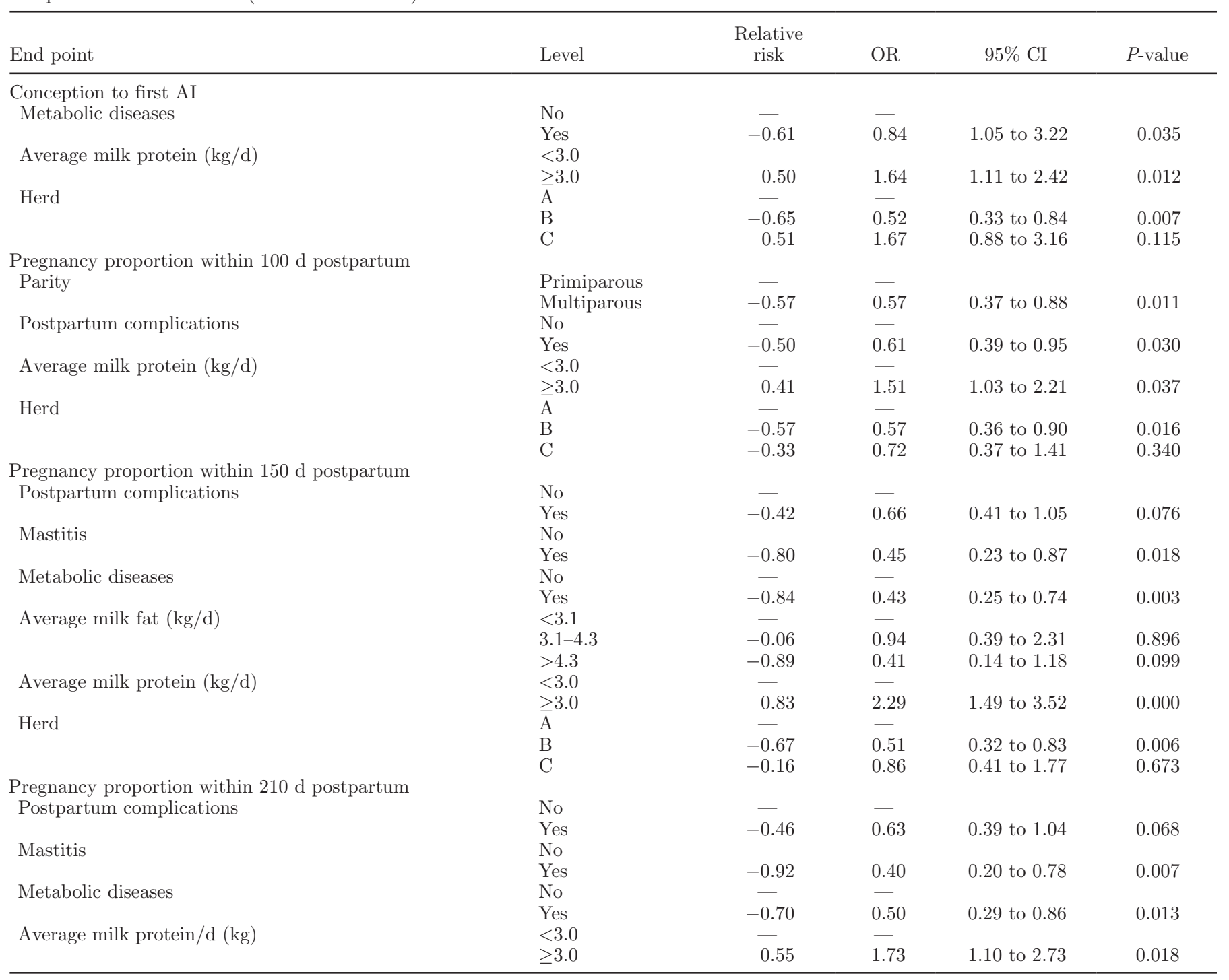

2008), and Lamming and Darwash (1998) reported the proportion of cows with PLP to be $6.9 \%$. The reasons for the difference in the incidence of PLP in different regions or herds may be related to differences in environmental and management factors.

Out of 59 cases of PLP, $64.4 \%$ were observed in the first cycle postpartum. The result that PLP was more frequent at the first cycle postpartum compared with the subsequent cycles agrees with previous reports (7.3 and 6.3\%, Lamming and Darwash, 1998; 18.2 and $16.8 \%$, Royal et al., 2000; and 16.0 and $11.0 \%$, Taylor et al., 2003). None of the cows showed PLP in 2 consecutive cycles.

Although almost all published studies on PLP share a common definition for the duration of PLP, $\geq 19$ or $\geq 20 \mathrm{~d}$, exact durations of PLP have not been well doc- umented in the literature. In the present study, based on twice-weekly sampling, PLP was categorized into different durations and we found that PLP durations of 20 to $23 \mathrm{~d}$ and 24 to $28 \mathrm{~d}$ were more frequent than those of 29 to $35 \mathrm{~d}$ and $>35 \mathrm{~d}$. Causes for the differences in the durations of PLP and the effect of PLP on fertility based on the duration warrants further investigation. More-frequent milk sampling (daily or 3 times a week) would enable precise and accurate studies on the duration of PLP.

No differences were found in maximum progesterone concentrations with increasing duration of PLP, but a PLP of $>35 \mathrm{~d}$ showed a significantly higher maximum progesterone concentration compared with that of shorter PLP. The reasons for the higher progesterone concentrations in longer PLP are not known. Frequent 
Table 7. Final Cox's proportional hazard regression models of reproductive performance end points in Holstein cows with prolonged luteal phase $(\mathrm{n}=497$ lactations)

\begin{tabular}{|c|c|c|c|c|}
\hline End point & Variable & $\mathrm{HR}^{1}$ & $95 \%$ CI & $P$-value \\
\hline & Normal ovarian resumption & - & & \\
\hline & Other abnormal ovarian resumptions & 0.57 & 0.46 to 0.70 & $<0.001$ \\
\hline \multicolumn{3}{|c|}{ Days to first insemination $^{2}$} & & \\
\hline & Prolonged luteal phase & 0.64 & 0.47 to 0.86 & 0.003 \\
\hline
\end{tabular}

${ }^{1}$ Hazard ratio (HR) of cows with prolonged luteal phase, relative to cows with normal resumption of ovarian activity postpartum.

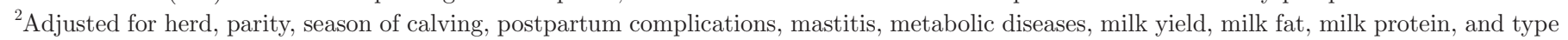
of ovarian resumption postpartum.

examinations of cows with PLP with ultrasonography and transrectal palpation in combination with milk or plasma progesterone measurements are essential to clarify the above relationship.

Because PLP is diagnosed based on milk progesterone concentrations, veterinarians and herd owners have little chance to diagnose and treat. It is, therefore, essential to identify cows at risk for PLP during the early postpartum period. Some possible factors influencing the occurrence of PLP have been analyzed in the current study. We observed that parity, commencement of luteal activity postpartum, postpartum complications, and average milk protein content during $90 \mathrm{~d}$ postpartum were significantly associated with the occurrence of PLP. Multiparous cows were 3.3 times more likely to have PLP. This is in agreement with the previous work (Opsomer et al., 2000; Pushpakumara et al., 2003; Samarütel et al., 2008). Opsomer et al. (2000) showed that cows that had calved 4 or more times were 2.5 times more at risk than first-parity cows. In the study reported by Samarütel et al. (2008), 54\% of PLP group cows were in their fifth or later lactations compared with $18 \%$ of cows in the normal group. According to Pushpakumara et al. (2003), PLP cows were of a higher average parity than the normal profile group (5.7 \pm 0.75 and $2.7 \pm 0.18)$. In contrast, some other researchers did not observe any significant association between parity and the prevalence of PLP in breeds such as Swedish Holstein, Swedish Red and White cows, and Norwegian Red cows (Petersson et al., 2006; Garmo et al., 2009). It has been suggested that uterine involution completes later in multiparous cows than in primiparous cows (Fonseca et al., 1983; Zain et al., 1995) and multiparous cows are more susceptible to metritis and pyometra (Erb and Martin, 1980; Etherington et al., 1985) and endometritis (Kim and Kang, 2003) compared with primiparous cows. An influence of parity on the days from calving to first ovulation has also been demonstrated in Holstein cows (Lucy et al.,
1992; Tanaka et al., 2008) as well as Swedish HolsteinFriesian and Swedish Red and White cattle (Petersson et al., 2006). All of the authors above reported that the first-parity cows had later onset of ovarian cyclicity. In our study, we observed a high incidence of PLP when luteal activity commenced $\leq 28 \mathrm{~d}$ postpartum. This may be one reason for primiparous cows to experience a lower incidence of PLP. These results are in agreement with the previous findings of Opsomer et al. (2000), who reported that cows showing their first progesterone increase within $24 \mathrm{~d}$ after calving were significantly at risk of having PLP. Petersson et al. (2006) also showed that cows with PLP had slightly earlier commencement of luteal activity compared with normal cows. It is known that when ovulation occurs before uterine involution, the risk for developing pyometra is greater (Farin et al., 1989; Opsomer et al., 1996).

Postpartum complications seem to be the most important factor influencing the occurrence of PLP. In this study, dystocia, retention of fetal membranes, endometritis, metritis, or pyometra were collectively categorized as postpartum complications. Cows showing one or more of these conditions were 5 times more likely to show PLP. Opsomer et al. (2000) reported that cows with metritis, problem calvings, and abnormal vaginal discharge were at significantly greater risk of having PLP. Taylor et al. (2003) observed in primiparous cows that uterine diameters at 28 to 35 d postpartum were significantly higher in cows with PLP in the first cycle compared with cows with normal progesterone profiles. They also observed a significantly higher incidence of vulval discharge in cows with PLP in both first and second cycles compared with cows with normal resumption of ovarian cycles postpartum. Endometritis has been reported by many researchers in both primiparous and multiparous Holstein cows with PLP (Shrestha et al., 2004a,b; Hommeida, et al., 2005; Petersson et al., 2006). Endometrial inflammation or any other abnormal uterine environment may compro- 


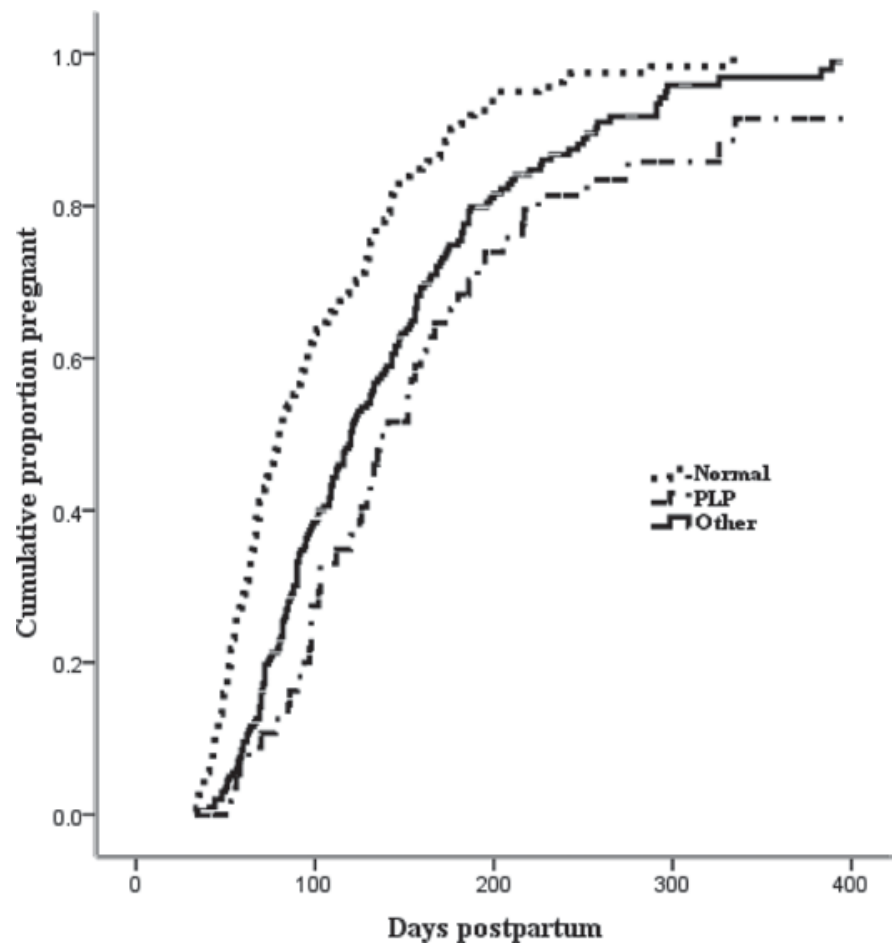

Figure 1. Kaplan-Meier survival function curves for the cumulative proportion pregnant against days postpartum for cows that had normal resumption of ovarian cyclicity postpartum (normal), prolonged luteal phase (PLP), or other abnormal ovarian resumptions postpartum (other); log rank statistics, $P<0.001$.

mise uterine ability to secrete $\mathrm{PGF}_{2 \alpha}$ by endometrium and transport $\mathrm{PGF}_{2 \alpha}$ to the ovary sufficiently to cause luteolysis, which results in PLP (Olson et al., 1984). As a result, the uterus is continuously under the influence of progesterone, favoring further bacterial growth. Some other studies have shown that cows with bacterial infection had prolonged rather than suppressed secretion of $\mathrm{PGF}_{2 \alpha}$ (Bekana et al., 1996a,b). More recently, inhibition of upregulation of the oxytocin receptor in bovine endometrium by IL-1, IL-2, or IL- 6 has been reported (Leung et al., 2001). These findings suggest that uterine infection may change the pattern of $\mathrm{PGF}_{2 \alpha}$ secretion to continuous production rather than the pulsatile pattern required for luteolysis (McCracken et al., 1999). It has been also suggested that long luteal phases associated with endometritis are probably caused by a switch in endometrial prostaglandin production from $\mathrm{PGF}_{2 \alpha}$ to $\mathrm{PGE}_{2}$ because of the components of microbes, such as LPS (Sheldon et al., 2009).

It has been reported that cows with PLP were heavier both before and after calving than cows with normal ovarian resumption (Shrestha et al., 2005). The metabolic clearance of steroid hormones is elevated with high feed intake in dairy cows, resulting in low peripheral estradiol concentrations (Sangsritavong et al., 2002),

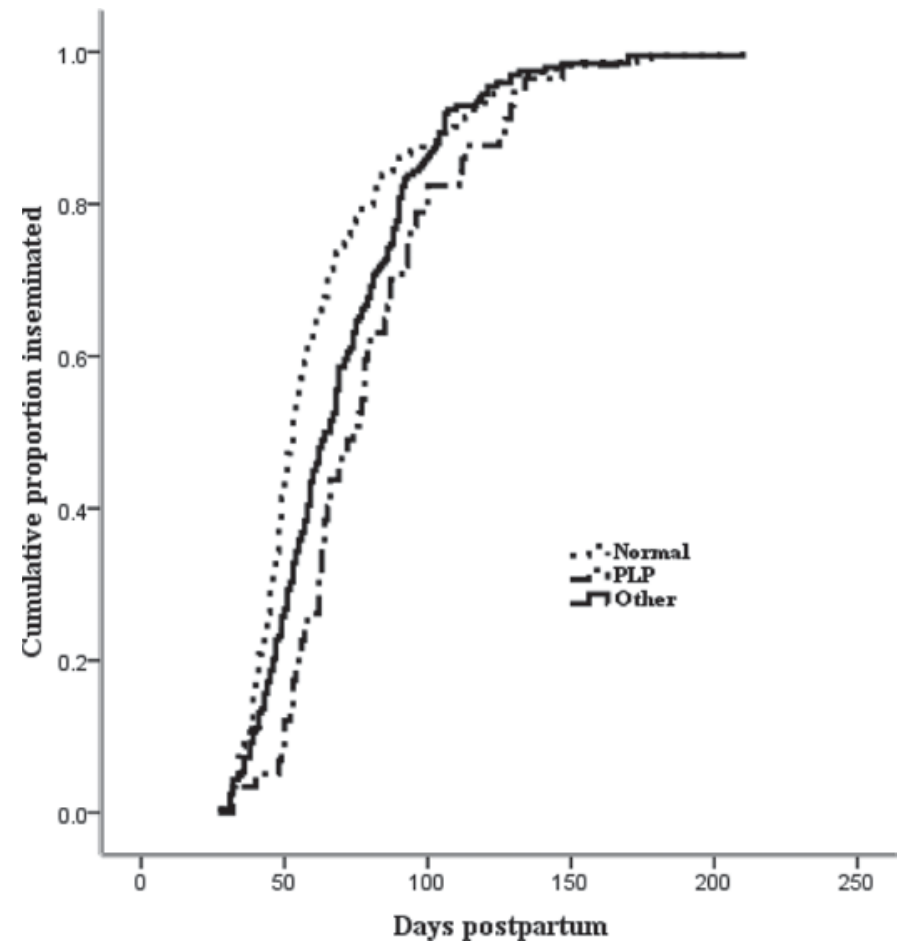

Figure 2. Kaplan-Meier survival function curves for the cumulative proportion inseminated against days postpartum for cows that had normal resumption of ovarian cyclicity postpartum (normal), prolonged luteal phase (PLP), or other abnormal ovarian resumptions postpartum (other); log rank statistics, $P=0.001$.

which can interfere with the process of luteolysis. In this study, cows with average milk protein content of $<3.0 \%$ during $90 \mathrm{~d}$ postpartum tended $(P=0.056)$ to show a high prevalence of PLP, and no effect of milk fat content on PLP was seen. Milk fat content was higher and milk protein content was lower in primiparous cows with PLP than in cows without PLP (Taylor et al., 2003). Samarütel et al. (2008) demonstrated a lower fat:protein ratio in the second month of lactation in cows with PLP compared with normal cows, but no difference was seen in fat or protein contents between the 2 groups in Estonian Holstein cows. In contrast to the study by Hommeida et al. (2005), in the present study milk yield was not significantly associated with PLP. Taylor et al. (2003) and Shrestha et al. (2005) also failed to show any relationship between PLP and milk yield in Holstein cows. However, it is difficult to discuss the relationship between nutritional status of the cows and PLP, because other nutritional parameters were not investigated in this study.

In the present study, cows with PLP showed a $53 \%$ reduction in first-service conception rate compared with normal cows. Pregnancy proportions within 100, 150, and $210 \mathrm{~d}$ were significantly lower and intervals from calving to first insemination and calving to conception 
were significantly longer in cows with PLP compared with normal cows. These results are in agreement with some of the previous reports (Lamming and Darwash, 1998; Royal et al., 2000; Shrestha et al., 2004a; Hommeida et al., 2005), but not with some other reports (Taylor et al., 2003; Samarütel et al., 2008; Gautam et al., 2010). Garmo et al. (2009) reported that the occurrence of PLP did not affect conception to first AI in Norwegian Red cows. The results of the study reported by Taylor et al. (2003) were based only on primiparous cows, which might explain the absence of adverse effects of PLP on reproductive performance in their study. Gautam et al. (2010) assumed that if there are no uterine infections, PLP might not adversely affect fertility.

As shown by this study and reported by some others studies (Shrestha et al., 2004a,b; Hommeida et al., 2005), uterine infections were clearly associated with PLP. Prolonged luteal phase in cows with incomplete uterine involution and uterine abnormalities may prevent animals coming into estrus, and hence show a longer interval to first insemination. It has been reported that ovulated cows that had completed uterine involution had a higher likelihood of pregnancy to first service compared with ovulated or anovulated cows that had not completed uterine involution (Mee et al., 2009). Furthermore, uterine damage by infection and incomplete uterine involution may persist, resulting in the absence of a conducive environment for attachment, growth, and development of the embryo, causing poor fertility in these cows (Shrestha et al., 2004b; Gilbert et al., 2005). This is further supported by the fact that animals with PLP became pregnant at a slower rate compared with normal animals and had a decreased pregnancy proportion even at $210 \mathrm{~d}$ postpartum compared with normal animals. Although PLP was associated with reduced pregnancy rate, PLP itself may not be the cause of the subfertility. It is well known that postpartum complications cause reduced pregnancy rate. Prolonged luteal phases caused by postpartum complications should be considered an indicator of the reduced pregnancy rate. On the basis of the results of the present study, we can state that the degree of uterine damage and higher parity associated with PLP may be the main factors that determine its effect on reproductive performance in dairy cows.

\section{CONCLUSIONS}

Occurrence of PLP was most frequent in the first cycle postpartum. Approximately $83 \%$ of PLP lasted 20 to 28 d. Cows with PLP $>35$ d showed significantly higher maximum progesterone concentrations compared with those with PLP lasting 20 to $35 \mathrm{~d}$. Cows with postpartum complications, early commencement of luteal activity postpartum, and multiparous cows were more likely to experience PLP. Prolonged luteal phase adversely affected subsequent reproductive performance in Holstein cows by decreasing pregnancy proportions and extending the calving to conception interval. Identification of cows that are at high risk for PLP is necessary for better management strategies and to minimize the adverse effects of PLP on fertility. Reducing postpartum complications and endometritis by improving nutritional status and the hygienic conditions around calving could lower the incidence of PLP. Early detection of endometritis and prompt treatment could minimize the adverse effects on fertility. A program in which progesterone can be measured in-line during milking would be a useful tool to control PLP in cows.

\section{ACKNOWLEDGMENTS}

The first author was supported by the Monbukagakusho scholarship of Japan, and the authors are thankful to the Ministry of Education, Culture, Sports, Science and Technology, Japan, for the financial support. The authors are also grateful to the farmers and the staff involved in this study for their cooperation. This study was supported by a Grant in-Aid for scientific research from the Japanese Society for the Promotion of Science (Tokyo; 20580353) and Japan Livestock Technology Association (Tokyo).

\section{REFERENCES}

Bekana, M., P. Jonsson, and H. Kindahl. 1996a. Intrauterine bacterial findings and hormonal profiles in postpartum cows with normal puerperium. Acta Vet. Scand. 37:251-263.

Bekana, M., K. Odensvik, and H. Kindahl. 1996b. Prostaglandin F $F_{2 \alpha}$ metabolite and progesterone profiles in postpartum cows with retained foetal membranes. Acta Vet. Scand. 37:171-185.

Erb, H. N., and S. W. Martin. 1980. Interrelationships between production and reproductive disease in Holstein cows. J. Dairy Sci. 63:1918-1924.

Etherington, W. G., S. W. Martin, I. R. Dohoo, and W. T. K. Bosu. 1985. Interrelationships between ambient temperature, age at calving, post partum reproductive events and reproductive performance in dairy cows: A path analysis. Can. J. Comp. Med. 49:254-260.

Farin, P. W., L. Ball, J. D. Olson, R. G. Mortimer, R. L. Jones, W. S. Adney, and A. E. McChesney. 1989. Effect of Actinomyces pyogenes and gram-negative anaerobic bacteria on the development of bovine pyometra. Theriogenology 31:979-989.

Fonseca, F. A., J. H. Britt, B. T. McDaniel, J. C. Wilk, and A. H. Rakes. 1983. Reproductive traits of Holsteins and Jerseys. Effects of age, milk yield, and clinical abnormalities on involution of cervix and uterus, ovulation, estrous cycles, detection of estrus, conception and days open. J. Dairy Sci. 66:1128-1147.

Garmo, R. T., A. D. Martin, E. Thuen, Ø. Havrevoll, H. Steinshamn, E. Prestløkken, Å. Randby, M. Eknæs, A. Waldmann, and O. Reksen. 2009. Characterization of progesterone profiles in fall-calving Norwegian Red cows. J. Dairy Sci. 92:4919-4928. 
Gautam, G., T. Nakao, K. Yamada, and C. Yoshida. 2010. Defining delayed resumption of ovarian activity postpartum and its impact on subsequent reproductive performance in Holstein cows. Theriogenology 73:180-189.

Gilbert, R. O., S. T. Shin, C. L. Guard, H. N. Erb, and M. Frajblat. 2005. Prevalence of endometritis and its effects on reproductive performance of dairy cows. Theriogenology 64:1879-1888.

Hommeida, A., T. Nakao, and H. Kubota. 2005. Onset and duration of luteal activity postpartum and their effect on first insemination conception rate in lactating dairy cows. J. Vet. Med. Sci. 67:1031-1035.

Isobe, N., T. Yoshimura, C. Yoshida, and T. Nakao. 2004. Incidence of silent ovulation in dairy cows during post partum period. Dtsch. Tierarztl. Wochenschr. 111:35-38.

Kim, I. H., and H. G. Kang. 2003. Risk factors for postpartum endometritis and the effects of endometritis on reproductive performance in dairy cows in Korea. J. Reprod. Dev. 49:485-491.

Lamming, G. E., and A. O. Darwash. 1998. The use of milk progesterone profiles to characterize components of subfertility in milked dairy cows. Anim. Reprod. Sci. 52:175-190.

Leung, S. T., Z. Cheng, E. L. Sheldrick, K. Derecka, A. P. F. Flint, and D. C. Wathes. 2001. The effects of lipopolysaccharide and interleukins- $1 \alpha,-2$ and -6 on oxytocin receptor expression and prostaglandin production in the bovine endometrium. J. Endocrinol. 168:497-508.

Lucy, M. C., C. R. Staples, W. W. Thatcher, P. S. Erickson, R. M. Cleale, J. L. Firkins, J. H. Clark, M. R. Murphy, and B. O. Brodie. 1992. Influence of diet composition, dry-matter intake, milk production and energy balance on time of post-partum ovulation and fertility in dairy cows. Anim. Prod. 54:323-331.

McCracken, J. A., E. E. Custer, and J. C. Lamsa. 1999. Luteolysis: A neuroendocrine-mediated event. Physiol. Rev. 79:263-323.

Mee, J. F., F. Buckley, D. Ryan, and P. Dillon. 2009. Pre-breeding ovaro-uterine ultrasonography and its relationship with first service pregnancy rate in seasonal-calving dairy herds. Reprod. Domest. Anim. 44:331-337.

Nakada, K. 2006. How to improve reproductive efficacy from now in Japan? Find out the factors of late lactation to predict postpartum reproductive diseases. J. Reprod. Dev. 52:177-183.

Olson, J. D., L. Ball, R. G. Mortimer, and P. W. Farin. 1984. Aspects of bacteriology and endocrinology of cows with pyometra and retained fetal membrane. Am. J. Vet. Res. 45:2251-2255.

Opsomer, G., M. Coryn, H. Deluyker, and A. de Kruif. 1998. An analysis of ovarian dysfunction in high yielding dairy cows after calving based on progesterone profiles. Reprod. Domest. Anim. 33:193-204.

Opsomer, G., Y. T. Grohn, J. Hertl, M. Coryn, H. Deluyker, and A. de Kruif. 2000. Risk factors for postpartum ovarian dysfunction in high producing dairy cows in Belgium: A field study. Theriogenology $53: 841-857$.
Opsomer, G., P. Mijten, M. Coryn, and A. de Kruif. 1996. Post-partum anoestrus in dairy cows: A review. Vet. Q. 18:68-75.

Petersson, K. J., H. Gustafsson, E. Strandberg, and B. Berglund. 2006. Atypical progesterone profiles and fertility in Swedish dairy cows. J. Dairy Sci. 89:2529-2538

Pushpakumara, P. G. A., N. H. Gardner, C. K. Reynolds, D. E. Beever, and D. C. Wathes. 2003. Relationships between transition period diet, metabolic parameters and fertility in lactating dairy cows. Theriogenology 60:1165-1185.

Royal, M. D., A. O. Darwash, A. P. F. Flint, R. Webb, J. A. Wooliams, and G. E. Lamming. 2000. Declining fertility in dairy cattle: Changes in traditional and endocrine parameters of fertility. Anim. Sci. 70:487-501.

Samarütel, J., K. Ling, A. Waldmann, H. Jaakson, T. Kaart, and A. Leesmae. 2008. Field trial on progesterone cycles, metabolic profiles, body condition score and their relation to fertility in Estonian Holstein dairy cows. Reprod. Domest. Anim. 43:457-463.

Sangsritavong, S., D. K. Combs, R. Srtori, L. E. Armentano, and M. C. Wiltbank. 2002. High feed intake increases liver blood flow and metabolism of progesterone and estradiol-17 $\beta$ in dairy cattle. J. Dairy Sci. 85:2831-2842.

Sheldon, I. M., S. B. Price, J. Cronin, R. O. Gilbert, and J. E. Gadsby. 2009. Mechanisms of infertility associated with clinical and subclinical endometritis in high producing dairy cattle. Reprod. Domest. Anim. 44:1-9.

Shrestha, H. K., T. Nakao, T. Higaki, T. Suzuki, and M. Akita. 2004a. Resumption of postpartum ovarian cyclicity in high producing Holstein cows. Theriogenology 61:637-649.

Shrestha, H. K., T. Nakao, T. Suzuki, M. Akita, and T. Higaki. 2005 Relationships between body condition score, body weight, and some nutritional parameters in plasma and resumption of ovarian cyclicity postpartum during pre-service period in high-producing dairy cows in a subtropical region in Japan. Theriogenology 64:855-866.

Shrestha, H. K., T. Nakao, T. Suzuki, T. Higaki, and M. Akita. 2004b. Effects of abnormal ovarian cycles during pre-service period postpartum on subsequent reproductive performance of high-producing Holstein cows. Theriogenology 61:1559-1571.

Tanaka, T., M. Arai, S. Ohtani, S. Uemura, T. Kuroiwa, S. Kim, and H. Kamomae. 2008. Influence of parity on follicular dynamics and resumption of ovarian cycle in postpartum dairy cows. Anim. Reprod. Sci. 108:134-143.

Taylor, V. J., D. E. Beever, M. J. Bryant, and D. C. Wathes. 2003 Metabolic profiles and progesterone cycles in first lactation dairy cows. Theriogenology 59:1661-1677.

Zain, E., T. Nakao, M. D. Raouf, M. Moriyoshi, K. Kawata, and Y. Moritsu. 1995. Factors in the resumption of ovarian activity and uterine involution in post partum dairy cows. Anim. Reprod. Sci. $38: 203-214$ 